\title{
Land Change Modeler for Analysing Diminishing of Vegetation in Bekasi
}

\author{
Herlawati $^{1}$, Fata Nidaul Khasanah ${ }^{1}$, Rafika Sari ${ }^{1}$, Prima Dina Atika ${ }^{1}$, Rahmadya Trias Handayanto ${ }^{2}$ \\ Faculty of Computer Science, Universitas Bhayangkara Jakarta Raya, Jakarta, Indonesia ${ }^{1}$ \\ Computer Engineering Department, Universitas Islam 45, Bekasi, Indonesia²
}

\begin{abstract}
Diminishing of vegetation is the main issue in Indonesia as a country with second largest forest in the world. It invites the increasing of global temperature and climate change. In local scale (province and regency level), the conversion from vegetation into another land type could lower the quality of life in such area. To prevent the decrease of vegetation, local governments have been trying to stop the conversion but it is difficult to ensure in daily activity with million people in those areas. Therefore, the objective mean is needed to monitor the numbers of vegetation in a region, e.g. satellite imagery and geographic information system. Satellite imageries can be used to analyse land cover change, especially the conversion from vegetation to other land covers. In this study, a land change modeler using two different dates of map was implemented after hard classification using iterative self-organising clustering in IDRISI Selva software. Decreasing vegetation trend and the direction of change can be seen after comparing two dates of land cover classification map.
\end{abstract}

Keywords: Satellite Imagery, Multispectral, ISOCLUST, Hard Classification

\section{INTRODUCTION}

Climate change and global temperature change are the main focus of sustainable development goals (SDGs) [1]. United Nations calls for every country to implement the SDGs concept in land use/cover planning, especially in city level since this kind of region is perceived as the source of environmental degradation [2]. Indonesia, a country having second largest rain forests needs a proper policy to protect the decrease of vegetation. Some urban areas appear in Indonesia and people needs a place for housing, office, industry and so on. Therefore, the conversion from vegetation to built-up land use type cannot be avoided without a strict policy.

Compared with the conversion from forest to palm oil plantation in Sumatra where large numbers of region are directly changed by burning a forest that causes forest fires, the conversion a vegetation in an urban area is slow but continuously happen. Without good monitoring by local governments, the massive conversion from vegetation into other types will occur day by day. After some years a lot of vegetation areas are converted into another type, e.g. residential, business areas, industry, etc. The fast and objective means are needed for monitoring because the reporting and data collection from the local government staffs might be there are some human error issues, for example research by [3] that comparing the number of building by satellite imagery and by census showed that there are a lot of different numbers. Satellite imagery has been implemented in land change modeler (LCM) to classify and predict the land use/cover change in a particular areas [4]-[6].

The current study uses Landsat satellite imagery to analyse vegetation change in Bekasi, West Java, Indonesia. Two dates of map are created based on satellite imageries after classification process. Some application can be used for modelling Land Use/Cover (LU/C), in this study, the TerrSet IDRISI 18.3 software was used. This application has been used by researchers for many purposes, e.g. classification, clustering, and LU/C change prediction [7].

After data and methods section, this paper will discuss the results. Some findings will be concluded in the conclusions section.

\section{DATA AND METHODS}

This study used raster data gathered from satellite imagery. Some classification methods, i.e. unsupervised classification (ISOCLUST) and supervised (RECLASS) were employed using IDRISI 18.3 software.

\section{A. Data}

Fig 1 shows the study area. It located in latitude and longitude of -6.241586 and 106.992416, respectively. Located in the east of Jakarta, capital city of Indonesia, the massive grow in this urban area is inevitable. 


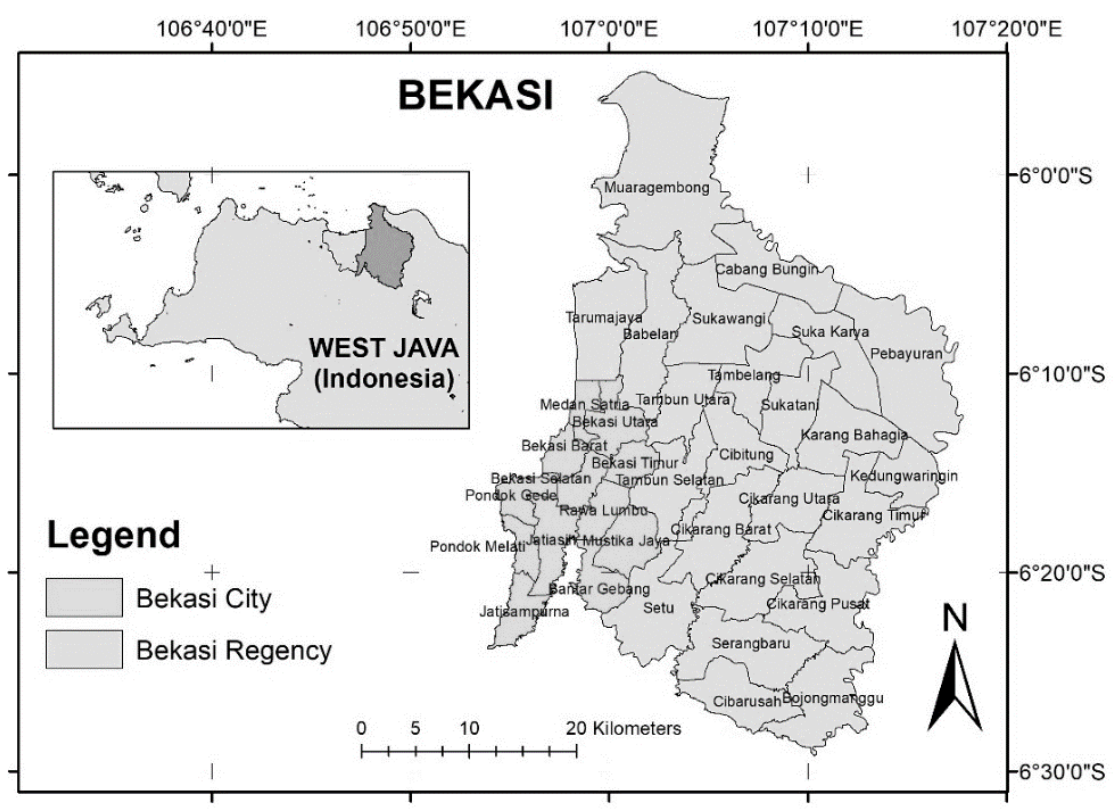

Fig. 1 Bekasi, West Java, Indonesia

Fig 1 shows the study area. It has latitude and longitude of -6.241586 and 106.992416, respectively. Bekasi is member of Jakarta Metropolitan Area located in the east of Jakarta, capital city of Indonesia, the massive grow in this urban area is inevitable. Fig 1 also show a vector data used in this current study. Another kind of data, i.e. raster data, was also used from satellite imagery.

Many sources of raster data can be used, e.g. aerial view, drone, etc. For large area, it is more efficient to use satellite imagery that now can be freely accessed from the internet. One of the satellite imagery vendor, United States Geological Survey (USGS) official site was used in this study to download two satellite imageries in different date as shown in Table 1.

TABLE 1. LANDSAT SATELLITE IMAGERY

\begin{tabular}{|l|l|l|}
\hline No. & Date & Sensor \\
\hline 1. & 13 September 2014 & Landsat 8 OLI/TIRS \\
\hline 2. & 15 August 2021 & Landsat 8 OLI/TIRS \\
\hline
\end{tabular}

There are 11 bands in the downloaded data after decompressing. IDRISI 19.3 was used to import these datasets. One true colour for each date was also downloaded and imported to help in re-classification using RECLASS function.

\section{B. Methods}

Fig 2 shows the framework of change detection using LCM. After downloading two dates of Landsat data from USGS, the ISOCLUST module in IDRISI was used to cluster into some classes, i.e. vegetation, water, and built-up. These classes were represented in different colour. A RECLASS function was needed to reclassify the clustering result into the proper land use/cover type. This process was done manually by comparing the clustering result with ground truth using a true colour map.

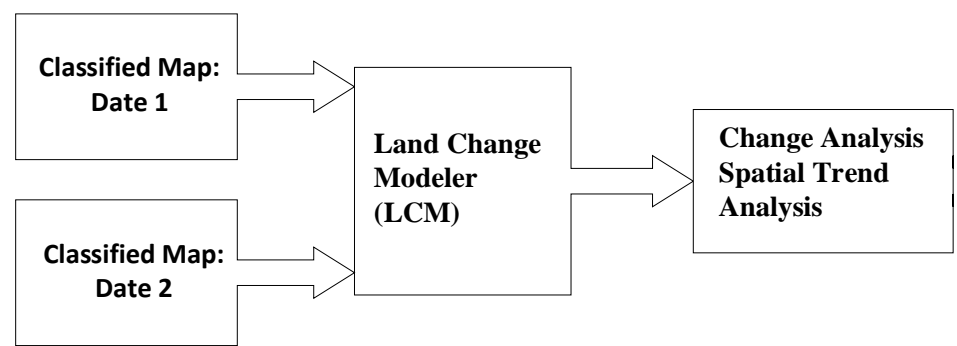

Fig. 2 Change Analysis Framework 


\section{International Journal of Advanced Research in Computer and Communication Engineering}

Vol. 10, Issue 8, August 2021

DOI 10.17148/IJARCCE.2021.10814

The next process after reclassification is clipping the classified raster according to the study area. A GIS tools, i.e. ArcMap was used for both clipping and ASCII map conversion for exporting to IDRISI. The projection used in this study is following the Geo-TIFF/TIFF data from USGS site, i.e. Universal Transverse Mercator (UTM) 48N. Change location can be analysed using the cross-tabulation method using CROSSTAB function.

LCM module in IDRISI was implemented using two classified maps. If the two maps have been compatible, the gain and lose table will appear. Change map and spatial trend of change can also be created to see the characteristics of land use/cover change (LUCC).

\section{III.RESULT AND DISCUSSION}

Many steps were involved in this study, i.e. downloading the Geo-TIFF data, importing to IDRISI 18.3, hard classification, reclassification, clipping following the study area, and LCM modelling.

\section{A. Downloading a Geo-TIFF Data}

To download from USGS, users should have registered. The cloud-free Landsat data according to a specific date can be accessed in many formats. The complete one has almost 1 Gigabyte data.

\section{B. Importing to IDRISI}

Geo-TIFF data should be converted into RST file in IDRISI using importing window. Geo-TIFF is a file TIFF with proper geospatial information, i.e. geographic coordinate and projection. The default projection from USGS for the study area, Bekasi, West Java, Indonesia is UTM 48N. There are 11 RST files after import process.

C. Hard Classification Result

This study used Iterative Self-Organizing Cluster Analysis (ISOCLUST) that is included in IDRISI 18.3 software. Fig 3 shows the clustering process with 18 class of LU/C. Seven band images were involved for clustering that can give the separation from a LU/C type to other types.

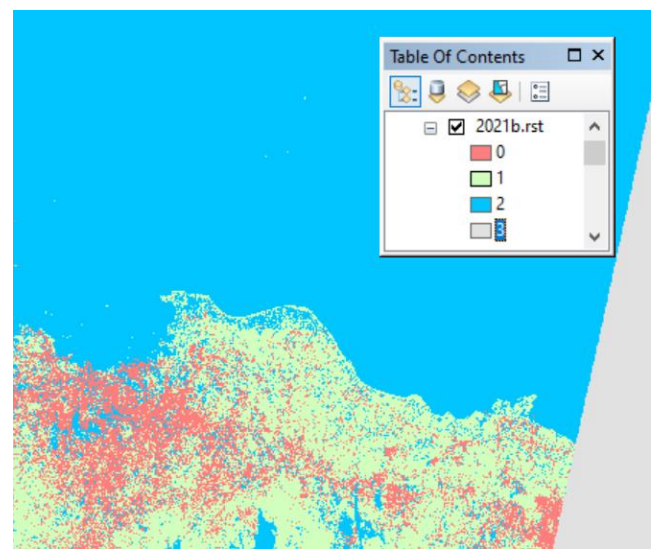

Fig. 3 Clustering Result (2021)

The similar technique is also done for 2014 clustering map. For analysing the decrease of vegetation, in this paper we merged the agriculture and forest/vegetation as well as built-up and other land use, e.g. road, and other land cover similar to built-up.

\section{Reclassification Result}

ISOCLUS result contain some clusters based on pixel image. The computer cannot give the exact LU/C of each cluster of pixels. Therefore, through the use of RECLASS function in IDRISI 18.3, 18 classified pixels can be classified into final class, i.e. built-up, vegetation, and water. A composite map which contains two maps, i.e. classification and true colour map was used for easily to classify. Fig 4 shows the reclassification result. 
Vol. 10, Issue 8, August 2021

DOI 10.17148/IJARCCE.2021.10814

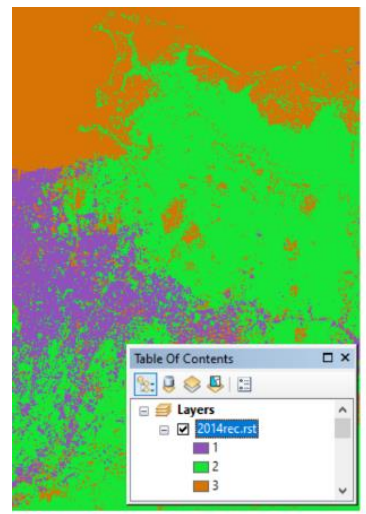

(A)

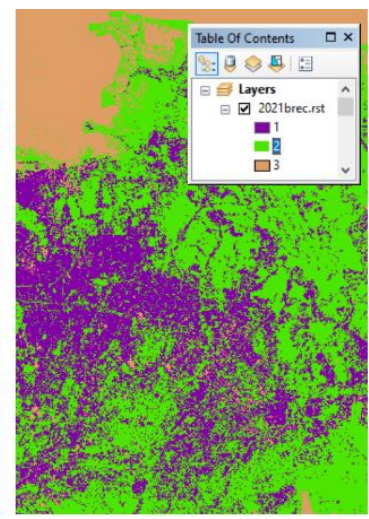

(B)

Fig. 4 Reclassification Result of 2014 (A) and 2021 (B)

Number 1,2, and 3 are built-up, vegetation, and water respectively. Visually, the built-up areas grow significantly from 2014 to 2021.

E. Change and Spatial Trend Analysis

To do a change and spatial trend analysis, two classified images should be match. A harmonization step is usually done for the first time. This include the legend and template matching. Two images for change analysis should have the same projection and extent.

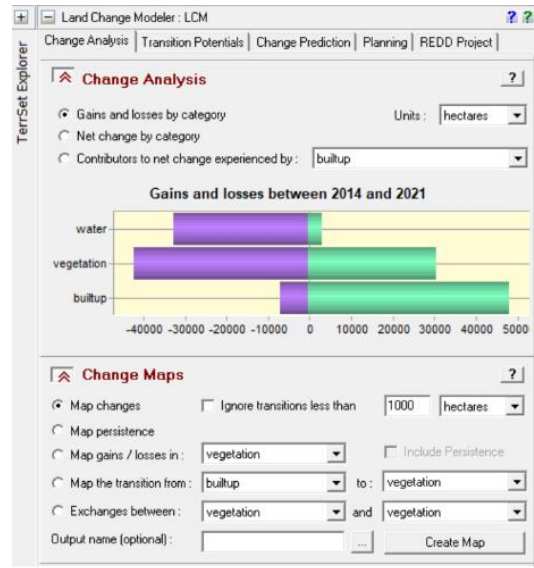

(A)

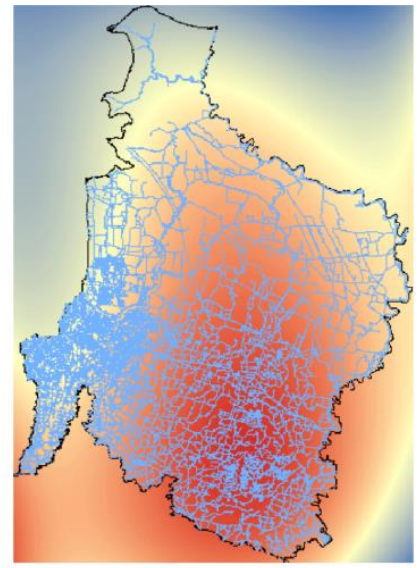

(B)

Fig. 5 Change Analysis (A) and Spatial Trend Analysis (B)

Fig 5.a shows the gains and losses from 2014 to 2021. Water and vegetation decrease, whereas the built-up area shows a dramatically increase. Fig $5 . b$ shows the spatial trend analysis where the read region shows the high conversion from vegetation to built-up.

\section{F. Discussion}

Current research on remote sensing analysis is a machine-learning-based analysis that combine pixel-based and objectbased in classification [8]-[16]. The purpose of such study usually to analyse LU/C change as well as future prediction of LU/C [17]. Table 2 shows the Cross Validation of 2014 and 2021 LU/C classification map.

TABle 2. PiXel CRoss TABUlation

\begin{tabular}{|c|c|c|c|c|c|}
\hline & \multicolumn{6}{|c|}{$\mathbf{2 0 1 4}$} \\
\hline \multirow{4}{*}{$\overline{\widetilde{~}}$} & Category & $\mathbf{1}$ & $\mathbf{2}$ & $\mathbf{3}$ & Total \\
\cline { 2 - 6 } & $\mathbf{1}$ & 378002 & $\underline{\mathbf{4 4 7 3 5 0}}$ & 90746 & 916098 \\
\cline { 2 - 6 } & $\mathbf{2}$ & 66779 & 1331602 & 273282 & 1671663 \\
\cline { 2 - 6 } & $\mathbf{3}$ & 13234 & 24102 & 516104 & 553440 \\
\cline { 2 - 6 } & Total & 458015 & 1803054 & 880132 & 3141201 \\
\hline
\end{tabular}




\section{International Journal of Advanced Research in Computer and Communication Engineering}

Vol. 10, Issue 8, August 2021

DOI 10.17148/IJARCCE.2021.10814

Chi-square $=2088554.5000, \mathrm{df}=4$, P-Level $=0.0000$,

Cramer's V $=0.5766$

There is $14.24 \%$ conversion from vegetation to built-up from 2014 to 2021 (bolt font in Table 2). The location of conversion based on Fig 4 is in the south of Bekasi, especially near the Cikarang, the biggest industrial areas in Indonesia. Many roads have been established that invite the conversion from vegetation to built-up. Therefore, the local government should consider this situation by following the sustainable development goals (SDGs) concept.

\section{IV.CONCLUSION}

The diminishing of vegetation is very dangerous to environmental conservation. The LCM showed the capability to analyze quantitatively numbers of endanger situation in a study area. The implementation of LCM in Bekasi, West Java, Indonesia showed a lot of number of vegetation land cover are converted into built-up class. The low oxygen supply would lower the comfort of people living in this area. Future study will add driving factors, e.g. roads, river, business areas, residential areas, etc. for predicting the LU/C change.

\section{ACKNOWLEDGMENT}

The authors thank to Universitas Bhayangkara Jakarta Raya in supporting this research as internal research grant. Also, for the reviewers who have given the insightful comments.

\section{REFERENCES}

[1] UN, "Habitat III Issue Papers - Public Space," in United Nation Conference on Housing and Sustainable Urban Development., 2015.

[2] F. Steiner, "The living landscape - An Ecological Approach to Landscape Planning - Second Edition,” Washington DC: ISLAND PRESS, 2008.

[3] L. Rahayu, S. Subiyanto, and B. Yuwono, "Kajian Pemanfaatan Data Penginderaan Jauh Untuk Identifikasi Objek Pajak Bumi Dan Bangunan (Studi Kasus : Kecamatan Tembalang Kota Semarang)," J. Geod. Undip, vol. 4, no. 1, pp. 20-31, 2015.

[4] S. S. Bhatti, N. K. Tripathi, V. Nitivattananon, I. A. Rana, and C. Mozumder, "A multi-scale modeling approach for simulating urbanization in a metropolitan region," Habitat Int., vol. 50, pp. 354-365, 2015.

[5] S.-H. Lee, K.-J. Han, K. Lee, K.-J. Lee, K.-Y. Oh, and M.-J. Lee, "Classification of landscape affected by deforestation using high-resolution remote sensing data and deep-learning techniques," Remote Sens., vol. 12, no. 20, pp. 1-16, 2020.

[6] E. A. Alshari and B. W. Gawali, "Development of classification system for LULC using remote sensing and GIS," Glob. Transitions Proc., vol. 2, no. 1, pp. 8-17, 2021.

[7] J. Eastman, "IDRISI selva tutorial. Idrisi production. Clark Labs-Clark Universit," 2012. [Online]. Available: https:/clarklabs.org/wpcontent/uploads/2016/10/TerrSet-Tutorial.pdf. [Accessed: 18-May-2019].

[8] Y. Chen, Z. Lin, Y. Chen, Z. Lin, X. Zhao, and S. Member, "Deep Learning-Based Classification of Deep Learning-Based Classi fi cation of Hyperspectral Data," vol. 7, no. June 2014, pp. 1-14, 2014.

[9] G. Rousset, M. Despinoy, and K. Schindler, "Assessment of Deep Learning Techniques for Land Use Land Cover Classification in Southern New Caledonia," pp. 1-22, 2021.

[10] W. Zhao, S. Du, and W. J. Emery, “Object-Based Convolutional Neural Network for High-Resolution Imagery Classification,” IEEE J. Sel. Top. Appl. Earth Obs. Remote Sens., vol. 10, no. 7, pp. 3386-3396, 2017.

[11] X. Zhang, G. Chen, W. Wang, Q. Wang, and F. Dai, "Object-Based Land-Cover Supervised Classification for Very-High-Resolution UAV Images Using Stacked Denoising Autoencoders,” IEEE J. Sel. Top. Appl. Earth Obs. Remote Sens., vol. 10, no. 7, pp. 3373-3385, 2017.

[12] A. Sharma, X. Liu, X. Yang, and D. Shi, "A patch-based convolutional neural network for remote sensing image classification," Neural Networks, vol. 95, pp. 19-28, 2017.

[13] S. K. Ojha, N. S. V. Yarlagadda, K. Challa, B. L. N. P. Kumar, and M. K. Vemuri, "Land Use Prediction On Satillite images using Deep Neural Nets," in Proceedings of the International Conference on Intelligent Computing and Control Systems (ICICCS 2019), 2019, pp. 999-1003.

[14] J. R. Bergado, C. Persello, and A. Stein, "LAND USE CLASSIFICATION USING DEEP MULTITASK NETWORKS," Int. Arch. Photogramm. Remote Sens. Spat. Inf. Sci., vol. XLIII, no. April 2016, pp. 17-21, 2020.

[15] T. T. Sasidhar, K. Sreelakshmi, M. T. Vyshnav, V. Sowmya, and K. P. Soman, "Land Cover Satellite Image Classification Using NDVI and SimpleCNN," in 2019 10th International Conference on Computing, Communication and Networking Technologies (ICCCNT), 2019, pp. 1-5.

[16] Q. Zou, L. Ni, T. Zhang, and Q. Wang, "Remote Sensing Scene Classification," IEEE Trans. Geosci. Remote Sens. Lett., vol. 12, no. 11, pp. 2321-2325, 2015.

[17] S. Lamine et al., "Quantifying land use/land cover spatio-temporal landscape pattern dynamics from Hyperion using SVMs classifier and FRAGSTATS®," Geocarto Int., vol. 33, no. 8, pp. 862-878, 2018.

\section{BIOGRAPHY}

Herlawati earned Magister Management and Magister of Computer Science. She has been published some books and papers in Data Mining, Machine Learning, and Geographic Information Systems. She is also a doctoral student of Computer Science in Bina Nusantara University. She is still active as lecturer at Universitas Bhayangkara Jakarta Raya 
Fata Nidaul Khasanah earned Master of Engineering in Electrical Engineering and Information Technology from Gadjah Mada University Yogyakarta. His profession is a lecturer since 2016 until now and is currently a permanent lecturer at Universitas Bhayangkara Jakarta Raya. The research focus are Decision Support System, Human Computer Interaction, Testing Implementation System, Internet of Things.

Rafika Sari has published some papers about computational science. She held academic position as lecturer of Informatics department in Universitas Bhayangkara Jakarta Raya.

Prima Dina Atika has published some papers about datamining and database. She is now a lecturer of Informatics department in Universitas Bhayangkara Jakarta Raya.

Rahmadya Trias Handayanto has published some papers about Geo-AI. After finishing his PhD in Information Management, he held academic position as head of computer engineering department in Universitas Islam 45 Bekasi. He is still active in reviewing some international journal and writing books. 